Rizki Aprison, Syamsirl Manajemen Kearsipan dalam Penyelenggaraan Administrasi Negara di Kantor Kejaksaan Negeri Padang

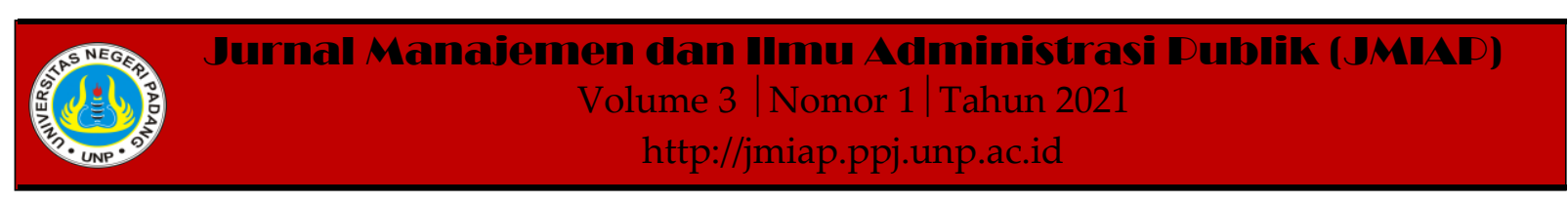

\title{
MANAJEMEN KEARSIPAN DALAM PENYELENGGARAAN ADMINISTRASI NEGARA DI KANTOR KEJAKSAAN NEGERI PADANG
}

\author{
Rizki Aprison ${ }^{1(a)}$, Syamsir $^{2(b)}$ \\ ${ }^{1}$ Jurusan Ilmu Administrasi Negara, Universitas Negeri Padang \\ ${ }^{2}$ Jurusan Ilmu Administrasi Negara, Universitas Negeri Padang \\ ${ }^{a)}$ rizkiaprison@gmail.com, ${ }^{b)}$ syamsirsaili@yahoo.com
}

\begin{abstract}
This research was conducted at the Padang Public Prosecutor's Office to describe archival management in the administration of state administration in the Padang District Attorney's office. The data collection technique was carried out by purposive sampling and snowball techniques, which means that data collection was carried out based on direct field results taken from interviews until the data obtained was saturated at the Padang District Attorney's office. The data analysis technique used in this research is descriptive analysis, which is to provide a comprehensive overview of the research. With the various methods used, it is hoped that this research can provide a clear and precise description of the data and problems that exist later. Archival management at the prosecutor's office has been carried out quite well, but the facilities and infrastructure are still simple and there are no archivist employees. However, the Padang District Attorney's office is trying to fix the problems of archival management with the attention of the leadership to the employees who manage the archives, adding facilities and infrastructure for archiving and as soon as possible to destroy archives that are no longer in use.

Keywords : Records Management, Letter, Archvist

Corresponding author. Email.rizkiaprison@gmail.com

How to cite this article. Aprison, R \& Syamsir. (2021). Manajemen Kearsipan dalam Penyelenggaraan Administrasi Negara di Kantor Kejaksaan Negeri Padang. Jurnal Manajemen dan Ilmu Administrasi Publik (JMIAP) Jurusan Ilmu Administrasi Negara Fakultas Ilmu Sosial Universitas Negeri Padang, Volume 3 (1), Hal. 1-10.

http://jmiap.ppj.unp.ac.id

Copyright@2021. Published by Labor Jurusan Ilmu Administrasi Negara FIS UNP, Padang
\end{abstract}


Rizki Aprison, Syamsir| Manajemen Kearsipan dalam Penyelenggaraan Administrasi Negara di Kantor Kejaksaan Negeri Padang

\section{PENDAHULUAN}

Selama praktik pekerjaan organisasi, himpunan tulisan mengenai berlangsungnya suatu kejadian dibuat tanpa komputer maupun dengan elektronik ,visual, rekaman suara, berwujud skrip serta audio visual, memiliki makna urgensi, dikelola beserta disimpan secara sistematis supaya tidak sulit ditemukan apabila suatu saat diperlukan dikenal dengan istilah arsip. Hal ini sebagai Instrumen pengingat pelaksana organisasi tentang sesuatu yang terjadi dimasa lalu (Mudhiah, 2018).

Tidak aneh lagi dikalangan kantor mengerjakan dan mengelola arsip, namun pekerjaan seperti itu sebenarnya tidak mudah. Pengelolaannya tidak sulit untuk kantor dengan ruang lingkup kecil, sebaliknya untuk sebuah kantor besar diperlukan keseriusan dan perhatian tinggi, menimbang perannya yang urgensi dalam setiap aktifitas kantor (Putri, 2015).

Pengendalian arsip tanpa alat elektronik yang sudah sudah pernah dikerjakan selama ini memiliki sejumlah kekurangan, seperti ; memerlukan penyimpanan besar, resiko kerusakannya oleh bencana, pegawai yang banyak, dan waktu penelusurannya lama. Sehingga, dibutuhkan solusi untuk mengatasi kelemahannya tersebut (Sutirman, 2015).

Banyak yang tidak menyadari maksud perlunya sebuah arsip, sehingga pengelolaan arsip inipun sering diremehkan.Hal ini terbukti masih ada organisasi baik itu organisasi pemerintah atau swasta membutuhkanbanyak waktu untuk penemuan kembali arsip.Situasi seperti ini sangat disayangkan, karena dapat menghambat pelayanan baik bagi internal organisasi maupun untuk eksternal organisasi (Kristiyanti, 2015).

Lembaga pendidikan, pemerintahan, dan swasta pasti memimpikan serta memerlukan administrasinya baik dalam pengelolaan dan manajemen arsipnya. Menyalin dokumen butuh dilaksanakan dalam wujud softfile atau hardfile meski seutuhnya tidak tertata rapi, karena masih banyak ditemukan salinan tulisan penting ketika diperlukan susah ditemukan. Jika kearsipan sebuah instansi tertata tidak rapi, pegawai kesusahan menemukan arsip yang urgensi dalam jangka waktu yang sedikit (Ari Wijaya, Budi Wiyono, \& Bafada, 2018).

Kejaksaan Negeri merupakan bagian dari pelaksana kekuasaan Kejaksaan Republik Indonesia yang tercantum dalam UU No.16 pasal 4 ayat (3) tahun 2004. Kejaksaan Negeri berkedudukan di ibu kota kabupaten/ kota dan daerah hukumnya meliputi wilayah kabupaten/kota. Kejaksaan Negeri dipimpin oleh seorang kepala kejaksaan negeri yang merupakan pimpinan dan penanggung jawab kejaksaan yang memimpin, mengendalikan pelaksanaan tugas, dan wewenang kejaksaan di daerah hukumnya pada bidang penuntutan. Arsip yang disimpan tentunya memerlukan pengelolaan yang baik agar memberikan banyak manfaat bagi instansi.

Pengelolaan arsip menjadi kurang optimal menyebabkan sejumlah permasalahan tampak, sehingga pengendaliannya tidaklah mudah. Dokumen di kantor ini makin bertambah, sehingga perlu pengolahan yang baik.

Pegawai di kantor Kejaksaan Negeri Padang dalam mengerjakan tugas pokoknya juga mengelola arsip, sehingga mengelola salinan tulisan tersebut keadaannya kurang dihiraukan. Perkara selanjutnya personel pengelola mengetahui bahwa dokumen kotor dan berdebu namun dibiarkan saja. Hal ini terkendala tanpa kehadiran arsiparis yang secara spesik ditugaskan mengolah pekerjaan tersebut, sehingga kedapatan pegawai merangkap kerja dan banyak duplikat warkat tersebut tidak terawat diakibatkan kurang pemeliharaannya.

Minimnya tempat penyimpanan arsip di Kantor Kejaksaan Negeri Padang tampak banyaknya penumpukan arsip di setiap ruang kerja, sedangkan lemari arsip sudah terisi penuh.Bertumpuknya arsip yang berlebihan di ruang kerja pegawai karena kurangnya tempat penyimpanan arsip mengakibatkan arsip menjadi berdebu dan beberapa mulai rusak. Kendala lain yang 
Rizki Aprison, Syamsir| Manajemen Kearsipan dalam Penyelenggaraan Administrasi Negara di Kantor Kejaksaan Negeri Padang

membuat penumpukan volume arsip di Kantor Kejaksaan Negeri Padang yaitu tidak dilakukannya penyusutan arsip. Arsip yang ada di Kantor Kejaksaan Negeri Padang selalu bertambah, akan tetapi tidak diimbangi dengan penyusutan. Tidak ada penyusutan arsip ini mengakibatkan volume arsip menjadi tidak terkendali dan akan mengganggu efisiensi pengelolaan arsip.

Banyak penumpukan arsip disetiap ruang kerja, tampak minimnya ruang penyimpanan di kantor Kejaksaan Negeri Padang yang lemarinya sudah terisi penuh. Bertumpuknya salinan tulisan mengakibatkan salinan tulisan beberapa mulai robek dan berdebu. Penghapusan dokumen yang belum dikerjakan menyebabkan makin naik jumlahnya, sehingga banyaknya salinan warkat itu mengganggu efesiensi pengelolaannya serta tidak terkendali.

\section{TINJAUAN PUSTAKA \\ Manajemen Kearsipan}

Seorang manajer yang baik adalah kemampuan seseorang memanfaatkan "pengganti otaknya" (serta"pikiran manusia lainnya") untuk mampu menyimpan peristiwa itu. Telah banyak upaya mengembangkan kekuatan "pengganti pikiran", umumnya dikenal dengan "arsip" yang terdiri atas warkat penting. Warkat merupakan catatan tertulis mengenai suatu hal yang bertujuan memberikan informasi, menjadi bahan bukti, bahan yang melukiskan sesuatu pada waktu yang telah lalu, dan untuk kebutuhan perekaman jejak administrasi (Komaruddin, 1993:191).

Arsip adalah catatan perihal peristiwa, namun menurut Suraja (2006:37) bisa dipahami bahwa arsip terdapat data ataupun informasinya dibutuhkan oleh setiap kumpulan pejabat ataupun orang maupun pegawai demi keperluan pelaksanaan kerja, pekerjaan baik, dan tugas fungsi didalam organisasi dan kebutuhan individual.

Menurut Komaruddin (1993:191-192) Kearsipan adalah proses penyusunan dan penyimpanan warkat asli, atau kopenya (salinannya) sehingga dengan cara itu,warkat tersebut dapat ditemukan dengan mudah jika diperlukan. Indeksasi terhadap arsip merupakan proses yang diperlukan agar warkat-warkat dapat ditempatkan. Dalam kearsipan, perencanaan, pelaksanaan dan pengawasan arsip tidak boleh dilakukan secara bermudah-mudah.

Sedangkan menurut Maryanti (2014:177) yang dikutip oleh Desi Putri (2015) Kearsipan mencorakkan Semua memo tertulis bentuk gambar, bagan serta menaruh keterangan mengenai suatu perdebatan utama atau peristiwa yang berguna dan diperlukan suatu saat dimasa yang akan datang.

Menurut E. Martono (1991:4) manajemen kearsipan adalah seni pengawasan surat berupa pengurusan pemakaiannya, pemeliharaan, perlindungan, serta penyimpanan surat. Pengendalian surat dengan rencana pembuatan, pemeliharaan sesuai dengan kepentingan surat, pemberian jasa pelayanan bagi yang membutuhkan surat, selanjutnya pemilihan surat yang perlu musnah atau perlu dijaga kelestariannya.

Odgers (dalam Sukoco, 2007:82) mendefenisikan manajemen arsip sebagai kiat penanganan, penyimpanan, dan pengamanan dokumen, baik dalam bentuk kertas maupun media elektronik.

Sedikit berbeda dengan pendapat sebelumnya, Charman (dalam Sukoco, 2007:82) mengartikan manajemen arsip sebagai prosedur yang yang menitikberatkan pada efesiensi administrasi perkantoran, pengelolaan dan pemusnahan dokumen apabila tidak diperlukan.

Lebih jelasnya, menurut Suraja (2006:62) Manajemen kearsipan adalah rentetan kegiatan mengelola seluruh elemen yang digunakan atau terlibat di dalam proses pengurusan arsip. Upaya pengelolaan arsip dilakukan melalui pelaksanaanfungsi perencanaan, pengorganisasian, penyusunan personalia, pengarahan dan pengendalian atau pengawasan terhadap arsip dan sumber daya yang ada untuk pengurusan kearsipan seperti pegawai (arsiparis, archievest), 
Rizki Aprison, Syamsir| Manajemen Kearsipan dalam Penyelenggaraan Administrasi Negara di Kantor Kejaksaan Negeri Padang

prasarana kearsipan dan keuangan yang dipergunakan untuk membiayai penyelenggaraan kegiatan kearsipan.

Sehingga, dengan demikian Manajamen Kearsipan adalah seni dalam kegiatan penyusunan dokumen asli yang berasal dari rekam hasil kegiatan yang telah dilaksanakan sebagai sumber ingatan organisasi dari awal organisasi tersebut berdiri dengan tujuan agar dokumen atau warkat tersebut mudah ditemukan kembali pada saat digunakan untuk kepentingan organisasi, seperti perencanaan, sebagai sumber sejarah, dan acuan pengambilan keputusan organisasi.

\section{Manajemen Kearsipan yang Ideal}

Sering dijumpai situasi pelayanan administratif sedang terhambat ditengah majunya zaman seperti sekarang. Oleh sebabnya, pelayanan masyarakat yang berhubungan dengan kegiatan kantor diminta mempunyai sistem kearsipan efisien dan efektif sehingga berjalan baik, jika tidak pemberian pelayanannya kepada masyarakat akan terhambat dan tidak memuaskan.

Salaha satu teori dari Suraja (2006:2526) beberapa kriteria pilihan harus ada dalam sistem kearsipan yang baik, seperti:

1. Tingginya tingkat tujuan kearsipan yang diperoleh, maknanya arsip sudah disimpan tidak ada cacat, tidak ada tercecer, sehingga dokumennya benar dan dapat dipakai pada waktu yang cepat serta dengan biaya sangat minim.

2. Dari perspektif elemen input, sistemnya dikatakan dalam keadaan baik apabila memenuhi kriteria tertentu seperti:

a) Mempunyai laporan dan evidensi yang betul, integral, relevan dan cocok.

b) Dalam menginput arsip, seorang pegawai mempunyai keahlian dan sifat tangkas, kritis, gesit, dan rapih dibidang kearsipan dalam melaksanakan kerja.

c) Kelengkapan dalam menginput arsip harus utuh seperti mencukupi jumlahnya, situasinya memuaskan, dan menuruti kemajuan teknologi kearsipan.

3. Dari sudut pandang cara atau rentetan pekerjaan kearsipan bagus diisyaratkan dengan adanya pelaksanaan, penciptaan, distribusi, penggunaan, pemeliharaan, penyimpanan dan penghapusan naskah dapat berjalan sesuai prosedur dan metode kerja telah ditentukan sehingga menghasilkan output yang benar.

4. Segi produksi oleh proses kearsipan, sebagai sekumpulan warkat yang mempunyai nilai lebih disimpan secara teratur, dan bila dibutuhkan mampu ditemukan kembali.

\section{Sarana Penyimpanan Arsip}

Penyimpanan arsip merupakan kegiatan penataan dan penyimpanan arsip yang sedemikian rupa dengan menggunakan sistem tertentu sehingga dapat mempermudah penemuan arsip kembali ketika dibutuhkan. Proses penyimpanan arsip dan penataan berkas di awali dari penampungan (penerimaan) arsip, pemeriksaan arsip untuk diklasifikasikan, pengindeksan, pengkodean, penyimpanan arsip, dan penataan berkas (Asriel dkk, 2016:137).

Menurut Asriel dkk (2016:137) untuk melakukan kegiatan penyimpanan arsip, diperlukan beberapa sarana penyimpanan. Beberapa sarana tersebut diantaranya adalah sebagai berikut:

1. Filling Cabinet. Filling Cabinet ialah perabot kantor yang berbentuk empat persegi panjang dan diletakkan secara vertical. Sehingga digunakan untuk menyimpan arsip/warkat yang sangat berharga bagi kelangsungan hidup suatu perusahaan atau organisasi.Media penyimpanan ini umumnya tersusun atas 4,5 atau 6 laci yang berurut ke bawah, terbuat dari bahan yang kuat, tahan lama, dan tidak membuat lembab.

2. Lemari Arsip. Lemari arsip ini berbentuk, seperti lemari biasa yang terdiri atas susunan rak-rak. Bahan pembuatan lemari ini dari bahan baja. 
Hal ini bertujuan untuk menghindari bahaya dari kebakaran. Lemari ini digunakan untuk menyimpan arsiparsip atau warkat.

3. Folder. Folder ialah Map yang berupa lipatan karton atau bahan lainnya dan memakai kawat penjepit atau tidak. Berguna untuk menyimpan arsip-arsip atau warkat.

4. Guide. Guide card (tanda pembatas/sekat petunjuk) ialah Sarana yang terbuat dari karton atau plastic tebal berfungsi sebagai petunjuk, pembatas atau penyangga deretan folder.

5. Map. Map ialah berbentuk sampul dari kertas tebal yang digunakan untuk menyimpan lembaran surat.

6. Rak Sortir. Suatu sarana berfungsi untuk memisahkan surat/ atau warkat yang diterima, diproses, dikirimkan maupun disimpan ke dalam masingmasing folder.

7. Kartu Indeks. Memiliki ukuran 15 x 10 $\mathrm{cm}$ dan berfungsi sebagai alat bantuan agar memudahkan dalam penemuan arsip kembali. Kartu indeks ini disimpan pada laci tersendiri disebut dengan laci kartu indeks.

\section{Penyusutan Arsip}

Penghapusan dokumen ialah kegiatan menghancurkan salinan surat dengan teknik tertentu sehingga tidak mampu dikenali lagi baik informasi maupun fisiknya. Tindakan ini bertujuan melindungi kelangsungan pengendalian memo dan menjaga keseimbangan hidupnya sejak diciptakan hingga akhirnya dimusnahkan serta menghindari bertumpuknya salinan surat yang tidak diperlukan lagi (Nurhasanah, 2010).

Nurhasanah (2010) prosedur pemusnahan arsip dilakukan secara total baik isi maupun bentuknya sehingga tidak dapat dikenali lagi, serta disaksikan oleh dua orang pejabat dari bidang hukum dan bidang pengawasan. Prosedur pemusnahan arsip sebagai berikut:
Pertama, ialah Pengusutan untuk mengetahui arsip tersebut betul habis jangka waktu penyimpanannya, maka dilaksanakan penyelidikan terlebih dahulu.

Kedua, yaitu Penataan Penyelenggara Penghancuran Arsip bila arsip yang akan dimusnahkan memiliki retensi 10 tahun/lebih dilaksanakan pembenahan panitia pemusnahan, cukup dilaksanakan oleh unit yang secara fungsional bertugas mengelola memo tersebut jika kurang dari 10 tahun maka tidak perlu dibuat kepanitian dalam penghapusan arsip.

Ketiga, Penjadwalan harus dibuat daftar pemusnahan secara jelas informasi sehingga dapat diketahui arsip yang akan dimusnahakan jika telah diperiksa dan diusulkan untuk dihapus, serta diketahui/disetujui oleh pejabat lembaga/badan terkait yang berwenang.

Keempat, sebelum dibuat Berita Acara Pemusnahan Arsip, penilaian, dan Persetujuan serta Pengesahan yang telah disepakati maka memo dihancurkan mendapat pengesahan.

Kelima, Berita Acara Pemusnahan merupakan bagian pekerjan penting diselenggarakan apabila melakukan penghancuran arsip. Dibuat dalam tiga rangkap dengan ketentuan lembar pertama diberikan kepada pimpinan lembaga/badan, lembar kedua pada unit pengolahan dan lembar ketiga untuk unit kearsipan masingmasing unit disimpan sebagai bukti pertanggungjawaban pembuangan arsip.

Keenam, Pelaksanaan Pemusnahan Arsip dapat dilaksanakan dengan 3 cara yaitu: dihancurkan menggunakan mesin pemusnah kertas, dibakar dan, dicacah dengan cara kimiawi.

Menurut Hamdani Fajri (2012) dalam Sulistyo-Basuki dalam (Sukonco, 2007:105) pemusnahan arsip dilakukan dengan beberapa cara yaitu:

Pertama, Pembakaran bertujuan agar dokumen yang rahasia tidak dapat diketahui orang lain apabila dilakukan dengan benar.

Kedua, Pencacahan ini dilakukan untuk memusnahkan dokumen dalam bentuk kertas dengan menggunakan alat pencacah 
Rizki Aprison, Syamsir| Manajemen Kearsipan dalam Penyelenggaraan Administrasi Negara di Kantor Kejaksaan Negeri Padang

yang dinamakan shredden. Alat ini menggunakan metode untuk memotong, menarik, dan merobek kertas menjadi sampai dengan $2,5 \mathrm{~cm}$.

Ketiga, Pembuburan Dokumen yang akan dimusnakan dimasukkan ke dalam bak penampungan yang diisi air, kemudian dicacah dan dialirkan melalui saringan. Metode ini merupakan metode yang ekonomis, aman dan bersih.

Keempat, Pemusnahan kimiawi Metode ini memusnahkan dokumen dengan menggunakan bahan kimiawi yang dapat melunakkan kertas dan melenyapkan tulisan.

\section{METODE PENELITIAN}

Penelitian ini menggunakan metode kualitatif dan dilakukan di kantor Kejaksaan Negeri Padang, penelitian ini meneliti manajemen kearsipan dan kendala serta upaya membenahi manajemen kearsipan di kantor Kejaksaan Negeri Padang. Pengumpulan data melalui observasi, wawancara, dan studi dokumentasi. Sedangkan uji keabsahan data dilakukan dengan teknik triangulasi sumber.

Penelitian ini dilakukan melalui teknik analisis data, yaitu proses mencari dan mengatur wawancara dan catatan di lapangan serta bahan-bahan lain yang telah dihimpun sehingga dapat merumuskan hasil dari apa yang telah ditemukan. Dimulai dari pengumpulan data, reduksi data, penyajian data, serta penarikan kesimpulan.

\section{HASIL DAN PEMBAHASAN}

\section{Manajemen Kearsipan di Kantor Kejaksaan Negeri Padang}

1. Tingkat pencapaian tujuan kearsipan yang tinggi

Berdasarkan temuan dalam penelitian, secara tingkat pencapaian tujuan kearsipan sudah baik, seperti arsip-arsip sudah dirapikan serapih mungkin, tidak ada yang hilang, rusak dan kertas arsip tersebut kebersihannya terjaga. Untuk biaya yang digunakan rendah karena biaya yang terpakai hanya memfotokopi surat yang diarsipkan.

a) Keadaan sistem kearsipan

Berdasarkan temuan dalam penelitian, data dan informasi yang disediakan dari arsip yang ada sudah lengkap dan benar. Dokumen yang sudah diarsipkan kantor kejaksaan negeri padang terdiri dari beberapa seperti ; SK CPNS, SK PNS, SK Naik Pangkat, SK Mutasi/Pindah, Kartu Pegawai, Kenaikan Gaji Berkala, dan Surat Nikah, berkas perkara, surat masuk biasa, surat keluar, BPKB kendaraan dinas, laporan bulanan, dan sertifikat tanah kantor kejaksaan negeri padang. Pegawai kearsipan secara khusus belum ada, jadi yang ada hanya pegawai tata usaha pada masing-masing bidang kantor kejaksaan negeri padang. Walaupun bukan pegawai khusus untuk manajemen kearsipan, pegawai pada kantor kejaksaan negeri padang di bidang masing-masingnya sudah mengelola arsip-arsip tersebut dengan baik menggunakan peralatan yang seadanya. Peralatan dan sarana yang digunakan untuk manajemen kearsipan yakni; map ordner, box file, dan filling cabinet tipe lateral cabinet.

b) Rangkaian kegiatan kearsipan

Berdasarkan temuan dalam penelitian, rangkaian kegiatan kearsipan pada kantor kejaksaan negeri padang umumnya hampir sama pada instansi dan lembaga pemerintahan umumnya. Pada awalnya surat maupun dokumen terlebih dahulu diregister kedalam buku surat masuk dan keluar, setelah itu surat tersebut diserahkan kepada yang bersangkutan dan menunggu disposisi dari yang bersangkutan. Jika sudah, sebelum surat didistribusikan sesuai disposisi, surat terlebih dahulu di fotokopi dan diarsipkan ke dalam map ordner berdasarkan kategori surat masuk dan disusun serta disimpan kedalam lemari arsip yang telah disediakan. Begitu juga surat keluar sebelum diarsipkan, surat keluar diberikan disposisi dahulu oleh yang bersangkutan, setelah itu surat distempel 
dan dinomori, kemudian sebelum surat di kirim ke instansi tujuan, surat keluar difotokopi kurang lebih satu lembar untuk diarsipkan kedalam map ordner dan disimpan dalam lemari arsip yang telah disediakan. Berkas perkara diarsipkan di ruang arsip Kejaksaan Negeri Padang jika proses penuntutannya selesai.

\section{c) Output kearsipan}

Berdasarkan temuan dalam penelitian, output kearsipan yang bernilai tinggi hampir pada semua arsip yang disimpan secara teratur, salah satunya dosir kepegawaian, berkas perkara dan laporan bulanan. Dosir kepegawaian merupakan himpunan data penting terkait informasi awal pegawai tersebut menjadi calon pegawai negeri sipil (CPNS), pegawai negeri sipil (PNS), Naik Pangkat, Mutasi/Pindah, Kartu Pegawai, Kenaikan Gaji Berkala, dan Surat Nikah, Arsip laporan bulanan juga sangat penting sebagai pertanggungjawaban kegiatan setiap bidang ketika ada inspeksi dari Kejaksaan Agung dan Kejaksaan. Sedangkan berkas perkara merupakan arsip dokumen para terpidana sejak terpidana ditangkap oleh pihak kepolisian hingga diadili di pengadilan oleh hakim.

\section{Kendala Kantor Kejaksaan Negeri Padang dalam Manajemen Kearsipan}

Manajemen kearsipan di kantor kejaksaan negeri padang sudah dilaksanakan cukup baik, namun masih ada ditemuka beberapa kendala. Untuk menjelaskan kendala manajemen kearsipan di kantor kejaksaan negeri padang, penulis melaraskan hasiltemuan penelitian dengan pandangan para ahli yang menyatakan beberapa kendala manajemen kearsipan.

Perkara yang pertama menjadi kendala dalam mengarsipkan surat-surat tersebut yang pertama itu meningkatnya jumlah surat yang disimpan ke dalam lemari arsip tanpa adanya pemusnahan arsip. Selama masa pandemi covid-19 yang menyebabkan kegiatan ekonomi menurun, sehingga peningkatan jumlah arsip yang dihasilkan kantor Kejaksaan Negeri Padang terus meningkat akibat meningkatnya tindak pidana yang terjadi ditengah krisis pandemi. Hal ini sesuai dengan salah satu hal yang diungkapka The Liang Gie (2000) ialah bertambahnya surat-surat kedalam lemari tanpa adanya penyusutan, sehingga tempat dan peralatan tidak mencukupi.

$$
\text { Perkara manajemen kearsipan }
$$

selanjutnya, terkendala pada pegawai arsiparis yang belum ada, pada umumnya seluruh pegawai non-jaksa kebih fokus kepada pekerjaan utamanya sesuai jabatannya masing-masing serta juga merangkap pekerjaannya dengan manajemen kearsipan. Pihak kantor kejaksaan negeri padang merasa terbantu jika ada mahasiswa yang melaksanakan praktik magang, sebab salah satu hal dasar yang diajarkan dalam kegiatan perkantoran adalah penataan arsip. Sebenarnya, melihat dari situasi itu, Hal ini sesuai dengan pernyataan Donni Juni Priansa (2013:168169) yang menyatakan bahwa kurangnya dipahaminya pengertian terhadap pentingnya arsip, mengakibatkan berfungsinya arsip sebagai pusat ingatan organisasi tidak tercapai, akhirnya tugastugas di bidang kearsipan dipandang rendah.

Sarana dan prasarana yang digunakan pada umumnya sudah ada, namun beberapa fasilitas tersebut ada yang kurang untuk kegiatan manajemen kearsipan.Sarana penyimpanan seperti lemari masih kurang untuk menyimpan arsip dan ukuran ruang penyimpanan tergolong masih sempit. Ragam peralatan untuk manajemen kearsipan kantor kejaksaan negeri padang sudah cukup terpenuhi., namun masih ada juga yang belum ada disediakan. Kartu index untuk surat yang diarsipkan dan cardex sebagai tempat penyimpanan kartu indeks belum ada disediakan. Hal ini sesuai dengan salah satu pendapat Moekijat (2002) yang menyatakan salah satu masalah yang sering dijumpai dalam administrasi kearsipan ialah ruang dan perlengkapan tidak sesuai dengan kegiatan. 
Rizki Aprison, Syamsir| Manajemen Kearsipan dalam Penyelenggaraan Administrasi Negara di Kantor Kejaksaan Negeri Padang

Upaya Kantor Kejaksaan Negeri Padang dalam Membenahi Manajemen Kearsipan.

Untuk membahas upaya kantor kejaksaan negeri padang dalam membenahi manajemen kearsipan, penulis menggunakan pandangan Emi Jumiyanti (2009) yang menegaskan bahwa ada beberapa upaya yang selaras dengan hasil temuan penulis untuk mengatasi permasalahan dalam manajemen kearsipan.

Upaya yang dibutuhkan untuk pegawai dan pegawai ialah perlu perhatian dan dukungan dari pimpinan kantor agar kegiatan manajemen kearsipan berjalan sebaik mungkin, serta agar arsip-arsip yang telah dikelola dengan baik agar tidak ada kerusakan maupun kehilangan arsip. Tujuan dari upaya ini juga mampu memperkuat kesadaran akan perlunya bidang kearsipan dalam keseluruhan proses administrasi dan menunjang berhasilnya upaya perbaikan dan penyempurnaan di bidang kearsipan.

Adanya pembinaan atau diklat untuk semua kegiatan perkantoran khususnya manajemen kearsipan yang secara berkelanjutan untuk meningkatkan keterampilan pegawai seiring perkembangan zaman yang semakin maju.Dengan demikian, adanya pembinaan atau pendidikan dan latihan yang merangkul semua aspek kearsipan bagi pejabat dan pelaksana kearsipan secara terarah, agar dapat mengimbangi perkembangan zaman serta dapat memenuhi syarat kualifikasi tertentu untuk manajemen kearsipan.

Upaya lainnya yang dilakukan untuk kendala manajemen kearsipan yakni dengan penambahan fasilitas.Penambahan fasilitas ini bertujuan untuk meningkatkan kapsitas penyimpanan arsip jika suatu saat arsip yang dihasilkan meingkat pesat, namun dibarengi dengan ketahanan fasilitas untuk menjaga keamaan arsip tersebut dari hal-hal yang tidak di inginkan.Serta merekrut pegawai khusus kearsipan agar tidak ada pegawai yang merangkap kerja serta untuk penyederhanaan tata kerja.
Begitu juga dengan pemusnahan, perlu penyusunan pemusnahan arsip yang sudah tidak terpakai lagi agar tidak menumpuk pada tempat penyimpanan. Surat-surat yang diarsipkan umumnya penting, namun perlu ada rencana untuk mengatur batas waktu nilai sebuah surat yang diarsipkan. Dengan adanya perencanaan pemusnahan, mampu untuk melonggarkan ruang penyimpanan dari arsip yang sebelumnya ditumpuk dalam waktu yang lama.

\section{PENUTUP}

Berdasarkan hasil penelitian dan pembahasan yang telah dilakukan oleh penulis, dapat disimpulkan bahwa manajemen kearsipan di kantor Kejaksaan Negeri Padang secara tingkat pencapaian tujuan kearsipan sudah baik, seperti arsiparsip sudah dirapikan serapih mungkin, tidak ada yang hilang, rusak dan kertas arsip tersebut kebersihannya terjaga. Untuk biaya yang digunakan rendah karena biaya yang terpakai hanya memfotokopi surat yang diarsipkan.

Dokumen yang diarsipkan kantor kejaksaan negeri padang terdiri dari ; SK CPNS, SK PNS, SK Naik Pangkat, SK Mutasi/Pindah, Kartu Pegawai, Kenaikan Gaji Berkala, dan Surat Nikah, berkas perkara, surat masuk biasa, surat keluar, BPKB kendaraan dinas, laporan bulanan, dan sertifikat tanah kantor Kejaksaan Negeri Padang. Pegawai kearsipan secara khusus belum ada dikarenakan dalam peraturan Jaksa Agung Republik Indonesia Nomor Per - 006/ A/ JA/ 07/ 2017 Tentang Organisasi dan Tata Kerja Kejaksaan Republik Indonesia pasal 957 bahwa Susunan Kejaksaan Negeri Tipe A tidak ada tercantum tentang Arsiparis, jadi hanya ada pegawai tata usaha pada masing-masing bidang kantor kejaksaan negeri padang. Meskipun bukan pegawai khusus untuk manajemen kearsipan, pegawai kantor kejaksaan negeri padang di masing-masing bidang sudah mengelola arsip tersebut dengan baik menggunakan peralatan yang seadanya. Peralatan dan sarana yang digunakan untuk manajemen kearsipan 
yakni; map ordner, box file, dan lemari arsip tipe lateral cabinet.

Rentetan aktifitas kearsipan pada kantor Kejaksaan Negeri Padang umumnya hampir sama pada instansi dan lembaga pemerintahan umumnya. Arsip-arsip surat yang dikelola kantor kejaksaan Negeri Padang, pertama diregister ke dalam buku surat masuk dan keluar, setelah itu surat diserahkan kepada yang bersangkutan dan menunggu disposisinya. Jika sudah, sebelum surat didistribusikan sesuai disposisi, surat terlebih dahulu di fotokopi dan diarsipkan ke dalam map ordner berdasarkan kategorinya dan disusun serta disimpan kedalam lemari arsip yang telah disiapkan. Berdasarkan temuan dalam penelitian, output kearsipan yang bernilai guna hampir pada semua arsip yang disimpan, salah satunya dosir kepegawaian, berkas perkara dan laporan bulanan. Dosir kepegawaian merupakan himpunan data penting terkait informasi awal pegawai tersebut menjadi calon pegawai negeri sipil (CPNS), pegawai negeri sipil (PNS), Naik Pangkat, Mutasi/Pindah, Kartu Pegawai, Kenaikan Gaji Berkala, dan Surat Nikah, Arsip laporan bulanan juga sangat penting sebagai pertanggungjawaban kegiatan setiap bidang ketika ada inspeksi dari Kejaksaan Agung dan Kejaksaan. Sedangkan berkas perkara merupakan arsip dokumen para terpidana sejak terpidana ditangkap oleh pihak kepolisian hingga diadili di pengadilan oleh hakim.

Manajemen kearsipan di Kantor Kejaksaan Negeri Padang sudah dilaksanakan cukup baik, namun masih ada ditemukan beberapa masalah. Kendala dalam mengarsipkan surat-surat tersebut yang pertama itu meningkatnya jumlah surat disimpan ke dalam lemari arsip tanpa adanya pemusnahan arsip. Selama masa pandemi covid-19 yang menyebabkan kegiatan ekonomi menurun, sehingga peningkatan jumlah arsip dihasilkan kantor Kejaksaan Negeri Padang terus meningkat akibat meningkatnya tindak pidana yang terjadi ditengah krisis pandemi.
Pegawai khusus untuk kearsipan belum ada, karena seluruh pegawai non-jaksa kebih fokus kepada pekerjaan utamanya sesuai jabatannya masing-masing serta juga merangkap pekerjaan utamanya dengan manajemen kearsipan.Sarana dan prasarana yang digunakan pada umumnya sudah ada, namun beberapa fasilitas tersebut ada yang kurang untuk kegiatan manajemen kearsipan.Sarana penyimpanan seperti jumlah lemari masih kurang untuk menyimpan arsip dan ukuran ruang penyimpanan tergolong masih sempit. Ragam peralatan untuk manajemen kearsipan kantor kejaksaan negeri padang sudah cukup terpenuhi., namun masih ada juga yang belum ada disediakan. Kartu index untuk surat yang diarsipkan dan cardex sebagai tempat penyimpanan kartu indeks belum ada disediakan.

Perlu perhatian dan dukungan dari pimpinan kantor agar kegiatan manajemen kearsipan berjalan sebaik mungkin, serta arsip-arsip yang telah dikelola dengan baik agar tidak ada kerusakan maupun hilang. Tujuan dari upaya ini ialah mampu memperkuat akan kesadaran betapa pentingnya bidang kearsipan dalam proses administrasi dan menunjang penyempurnaan di bidang kearsipan. Selain itu, pembinaan atau diklat untuk semua kegiatan perkantoran khususnya manajemen kearsipan yang secara berkelanjutan untuk meningkatkan keterampilan pegawai seiring perkembangan zaman yang semakin maju. Dengan demikian, adanya pembinaan, pelatihan, pendidikan dan latihan untuk merangkul pejabat dan pelaksana kearsipan secara terarah agar dapat mengikuti perkembangan zaman sehingga dapat memenuhi syarat kualifikasi tertentu untuk manajemen kearsipan.

Upaya lainnya yang dilakukan untuk kendala manajemen kearsipan yakni dengan penambahan fasilitas.Penambahan fasilitas ini bertujuan untuk meningkatkan kapsitas penyimpanan arsip jika suatu saat arsip yang dihasilkan meingkat pesat, namun dibarengi dengan ketahanan fasilitas untuk 
Rizki Aprison, Syamsir| Manajemen Kearsipan dalam Penyelenggaraan Administrasi Negara di Kantor Kejaksaan Negeri Padang

menjaga keamanan arsip tersebut agar terhindar dari hal-hal yang tidak di inginkan. Dan merekrut pegawai khusus kearsipan agar tidak ada pegawai yang merangkap kerja serta untuk penyederhanaan tata kerja. Begitu juga dengan pemusnahan, perlu dilakukan penyusunan dalam pemusnahan arsip yang sudah tidak terpakai lagi sehingga tidak menumpuk pada tempat penyimpanan. Surat-surat yang diarsipkan umumnya penting, namun perlu ada rencana untuk mengatur batas waktu nilai sebuah surat yang diarsipkan. Dengan adanya perencanaan pemusnahan, mampu untuk melonggarkan ruang penyimpanan dari arsip yang sebelumnya ditumpuk dalam waktu yang lama.

\section{DAFTAR KEPUSTAKAAN}

A.W, Widjaja.1986.Administrasi Kearsipan: Suatu Pengantar. Jakarta: Rajawali.

Asriel, A. S., Armiati, \& Frista, L. (2016). Manajemen Kantor. Jakarta: Kencana.

Gie, The Liang. 2000. Administrasi Perkantoran Modern. Yogyakarta: Liberty.

Hamdani, F., \& Syahyuman. (2012). Sistem Pengelolaan Arsip Dinamis Aktif di Kantor Perpustakaan, Arsip, dan Dokumentasi Kabupaten Pesisir Selatan. Jurnal Ilmu Informasi Perpustakaan dan Kearsipan Vol. 1, No. 1, 409-417.

Komaruddin. (1993). Manajemen Kantor Teori dan Praktek. Bandung: Trigenda Karya.

Kristiyanti, I. (2015). Manajemen Kearsipan Dalam Meningkatkan Kualitas Pelayanan. Efisiensi, XIII, 85-97.

Martono, E. 1991. Kearsipan Rekord Manajemen dan Filling dalam Praktek
Perkantoran Modern. Jakarta: Karya Utama.

Moekijat, 2002. Tata Laksana Kantor Manajamen Perkantoran. Bandung: Penerbit Mandar Maju.

Moekijat. (1989). Tata Laksana Kantor Manajemen Perkantoran. Bandung: Mandar Maju.

Moekijat. 1997. Administrasi Perkantoran. Bandung: Mandar Maju.

Moleong, L. J. 2012. Metode Penelitian Kualitatif. Bandung: PT Remaja Rosdakarya

Priansa, D. J., \& Garnida, A. (2013). Manajemen Perkantoran Efektif, Efisien, dan Professional. Bandung: Alfabeta.

Sugiyono. 2014. Metode Penelitian Kuantitatif Kualitatif dan $R \& D$. Bandung: CV Alfabeta.

Sukoco, Badri Munir. 2007. Manajemen Administrasi Perkantoran Modern. Jakarta: Erlangga

Suraja, Yohannes. 2006. Manajemen Kearsipan. Malang: Dioma.

Surojo, 2006. Manajemen Kearsipan. Jakarta: PT. Bumi Aksara.

Sutirman. (2015). Urgensi Manajemen Arsip Elektronik. Efisiensi, 13(February), 96-109.

UU No. 16 pasal 4 ayat (3) tahun 2004. 